\title{
Do Multinational Companies Practice Good Corporate Governance? Empirical Evidence from Bangladesh
}

\author{
G. M. Wali Ullah (Corresponding author) \\ Lecturer, Department of Finance \\ School of Business, Independent University, Bangladesh (IUB) \\ Plot 16, Block B, Bashundhara R/A, Dhaka-1212 \\ E-mail: wali@iub.edu.bd \\ Sarwar Uddin Ahmed \\ Professor and Dean, School of Business \\ Independent University, Bangladesh (IUB) \\ Plot 16, Block B, Bashundhara R/A, Dhaka-1212 \\ Samiul Parvez Ahmed \\ Assistant Professor and Head, Department of Finance \\ School of Business, Independent University, Bangladesh (IUB) \\ Plot 16, Block B, Bashundhara R/A, Dhaka-1212
}

Kazi Md. Jamshed

Lecturer, Department of International Business

University of Dhaka, Bangladesh

Received: September 12, 2017 Accepted: September 21, 2017 Published: November 12, 2017 doi:10.5296/ijafr.v7i2.11843

URL: https://doi.org/10.5296/ijafr.v7i2.11843 


\section{Macrothink Interational Jornal of Acesenting and Finactil Reporting ISSN 2162-3082 2017, Vol. 7, No. 2}

\section{Abstract}

Corporate Governance refers to the way an organization is directed, administrated or controlled. It includes the set of rules and regulations that affect the manager's decision and contribute to the way company is perceived by the current and potential stakeholders. The corporate governance structure specifies the distribution of rights and responsibilities among different participants in the corporation such as; boards, managers, shareholders and other stakeholders and spells out the rules and procedures and also decision-making assistance on corporate affairs. Corporate governance practices in Bangladesh are gradually being introduced in most companies and organizations ( $\mathrm{Du}, 2006)$. However, Bangladesh has fallen behind its neighboring countries and global economy in corporate governance (Gillibrand, 2004). Corporate governance structure is mainly considered ambiguous. Specific governance structures or practices will not necessarily fit all companies at all times. Firms with strong corporate governance mechanisms are generally associated with better financial performance, higher firm valuation and higher stock returns. Unfortunately, investors in Bangladesh have a little information about how these corporate values affect the performance of the Multinational Companies (MNCs). This study aims to provide a quantitative contribution to the literature by examining the impact of corporate governance mechanisms on financial performance from the perspective of MNCs. A panel data based Ordinary Least Squared (OLS) regression model was used to measure the quantitative significance of various corporate governance related variables on MNC performance, as identified through a detailed literature review.

Keywords: corporate governance, multinational company (MNC), financial performance, Bangladesh

\section{Background of the Study}

Corporate governance describes the structure of rights and responsibilities among the parties that have a stake in a firm (Aguilera \& Jackson, 2003). A corporate governance system can be a set of processes and structures used to direct a corporation's business. A key objective of a corporate governance system should be the enhancement of shareholder wealth. Once implemented, an effective corporate governance system can help to ensure an appropriate division of power among shareholders, the board of directors, and management (Mcconomy $\&$ Bujaki, 2000). Firms with strong corporate governance mechanisms are generally associated with better financial performance, higher firm valuation and higher stock returns (Ammann, Oesch, \& Schmid, 2011; Bebchuk, Cohen, \& Ferrell, 2009; Brown \& Caylor, 2006; Cremers \& Ferrell, 2009; Gompers, Ishii, \& Metrick, 2001; Johnson, Moorman, \& Sorescu, 2009; Renders, Gaeremynck, \& Sercu, 2010).

Bangladesh is one of the emerging markets and most of the top companies are either family owned or controlled by corporate group or government. Corporate governance practices in Bangladesh are gradually being introduced in most companies and organizations. 66.7 percent of the companies have adopted corporate governance and 43.3 percent have compliance policy with national or international benchmarks. However, Bangladesh has lagged behind its neighbors and the global economy in corporate governance. One reason for 


\section{MlMacrothink}

International Journal of Accounting and Financial Reporting

ISSN 2162-3082

2017, Vol. 7, No. 2

this slow progress in adopting corporate governance is that most companies are family oriented. Such concentrated ownership structures affect the effectiveness of corporate governance mechanisms, which weaknesses cannot be rectified by laws and regulations. Motivation to disclose information and improve governance practices by companies is also felt negatively. There is neither any value judgment nor any consequences for corporate governance practices. The current system in Bangladesh does not provide sufficient legal, institutional and economic motivation for stakeholders to encourage and enforce corporate governance practices ( $\mathrm{Du}, 2006)$.

Corporate governance in MNCs shares many common elements with corporate governance in domestic firms. Conventional mechanisms of corporate governance such as ownership concentration, board member participation, and executive compensation apply to both. Still, however, corporate governance differs between MNCs and domestic firms in several ways. For example, MNCs have to deal with more demanding and diverse global shareholders and stakeholder groups that seek greater disclosure and more transparent explanations for major decisions (Freeman \& Reed, 1983). Also, as a growing number of MNCs become listed on multiple exchanges in multiple countries, and certain overseas units become independently listed on host country exchanges, MNC corporate governance has also become much more complex and subject to many more institutional constraints. However, most of the listed companies in Bangladesh except multinationals are dominated by family members, occupying important posts such as the CEO or the managing director, leading to inefficient governance practices (Brennan, Solomon, Uddin, \& Choudhury, 2008). Almost no study exists highlighting the effect of corporate governance on multinationals from the perspective of Bangladesh, or much on any other developing markets. Therefore, this research will aim to look at how the listed MNCs of Bangladesh has integrated these issues and having an impact on firm profitability.

\section{Literature Review}

Generally, corporate governance is perceived as an organizational-wide ethical practice that considers different stakeholders (i.e. shareholders, creditors, employees, customers, regulators) in an integrated framework (Al-Malkawi, Pillai, \& Bhatti, 2014). Specifically, corporate governance could be defined as a set of rules and policies to govern various activities of an organization with that of its stakeholders and these policies and rules are legitimated by legal authorities/bodies and protected by the Government (Alam Choudhury \& Nurul Alam, 2013). From an organizational management perspective, corporate governance can be defined as an ethical mechanism to guide overall activities of an organization keeping in mind the objective of the firm, as different interests, often conflicting, of various stakeholders could hinder the process of achieving organizational goal. This issue of conflicting interests of different stakeholder and their influence on achieving organizational goal is popularly known as agency conflict-conflict between managers (agent) and shareholders (principal) (Kasri, 2009). Thus, in one sense, one of the crucial tasks of the corporate governance is to minimize agency conflict of an organization. Moreover, if an organization's activities are extended beyond national border, the likeliness of agency conflict increases due to several factors (e.g. geographic distance of the subsidiaries, 
differences in values and norms of the employees of host nation) and, thus, corporate governance issues become more complex for MNCs (Madura, 2012). The last two decades have witnessed a continuing trend of deregulation and integration of capital markets, accompanied by major events in the financial world. The financial scandals resulting from accounting frauds and earnings management in such large players as Enron, WorldCom, and Adelphia were primarily blamed on the behavior of top executives and their excessive risk taking that does not serve the best interest of shareholders (and other stakeholders in the firm). Thus, various international authorities/bodies developed policies to ensure that the MNCs comply with global ethical standards.

Researchers have used different variables as common tools to implementing and measuring the effectiveness of corporate governance mechanism in companies. One of the most used variables is CEO duality, that the position of the Chief Executive Officer (CEO) and the chairman of the board are being served by the same individual (Bhagat \& Bolton, 2013). It is the responsibility of the board of directors to make sure that the CEO is serving the interests of the shareholders in the best possible way. In that sense, the board of directors can be seen as a monitoring device that makes sure that the interests of the CEO are the same to that of the shareholders (Finkelstein \& D'aveni, 1994). Hence, the relationship between the chairman of the board and that of the CEO is essential (Tricker, 1984). Firms will have to choose whether or not the same person fulfills the role of CEO and chairman of the board. A fundamental element of the management of a corporation is the leadership structure of the board. Finkelstein et al. (1994) are also in favor of this point of view. They assert that CEO duality may be one of the most vital, disputed and inconclusive issues in corporate governance research and practice. One argument in favor of CEO duality is that there will be additional costs when the roles of CEO and chairman are separated. Coles \& Jarrell (1997) assert that monitoring costs arise when the CEO and chairman are separated. The benefits of monitoring can be more than the costs in many cases. Another research concluded that the costs of separating the CEO and the chairman outweigh the benefits. In addition to lower costs, CEO duality can also benefit firm performance because a single leader can give a clear direction and can be more responsive to changes (Brickley, Coles, \& Jarrell, 1997). Also, one person assuming the role of both CEO and chairman will have more extensive knowledge of the organization and will also be more committed (Boyd, 1995). However there are contrasting arguments existent in several studies as well. Goyal \& Park (2002) conclude that CEO turnover to firm performance is significantly lower in the case of CEO duality. They attribute this conclusion to the fact that it is more difficult for the board to remove CEO's that are also the chairman. In the case of failure, it is extremely difficult for the board to remove the top management team (Jensen, 1993). Rechner et al. (1991) provided empirical support making the case for the separation of the CEO and chairman. In their study, they use accounting based performance measures that reveal that firms with a separation of CEO and chairman outperform firms with CEO duality.

There are numerous other variables that researchers commonly used to measure the impact of corporate governance tools. Board size - the number of both executive and non-executive directors making up for the complete board of directors is considered one of the central factor 


\section{Mll Macrothink}

International Journal of Accounting and Financial Reporting ISSN 2162-3082 2017, Vol. 7, No. 2

of effective corporate governance (Bonn, Yoshikawa, \& Phan, 2004; Panasian, Prevost, \& Bhabra, 2003). Identifying appropriate board size that affects its ability to function effectively has been a matter of continuing debate (Jensen, 1993). Lipton and Lorsch (1992) support small boards, suggesting that larger groups face problems of social loafing and free riding. As board increase in size, free riding increases and reduces the efficiency of the board. On the other hand, large boards were supported on the ground that they would provide greater monitoring and advice (Coles, Daniel, \& Naveen, 2008). Studies show that board size varies across different countries depending on their culture and company structure - with no optimal board size determined (Zabri, Ahmad, \& Wah, 2016). One study across European originated firms found that in the United Kingdom, Switzerland and Holland, they are more likely to have a small board size while Belgium, France, Spain and Germany tend to have a large board size consisting 13 to 19 members (Heidrick, 2007). However, many researchers seem to support smaller board sizes, as it ensures better coordination, accountability, and quick decision making (Cerbioni \& Parbonetti, 2007; Morekwa Nyamongo \& Temesgen, 2013; Tornyeva \& Wereko, 2012). In particular, studies in the UK and in Malaysia and Singapore showed firm's performance at its peak when it is five and not more than seven or eight (Florackis, 2008; Mak \& Kusnadi, 2005). While no optimal board size was determined, it has been strongly implied in many empirical studies that board size has an essential role in management of the firm and firm performance (Ehikioya, 2009). However, mixed results exist in how board size affects firm profitability. Some studies showed a positive relationship between these two across a wide array of sample countries (Mak \& Kusnadi, 2005; Shukeri, Shin, \& Shaari, 2012; Zabri et al., 2016). However, contrasting findings were also found in some studies, as they demonstrated a negative association between firm size and profitability in both developed and emerging markets (Aldehayyat, Alsoboa, \& Al-Kilani, 2016; Morekwa Nyamongo \& Temesgen, 2013; Obradovich \& Gill, 2012, 2013).

Even among the board members, the presence of female members is considered significant as such diversity increases market understanding, community image and career development among staff members (Smith, Smith, \& Verner, 2006). Diversity in broad-spectrum is considered to enhance organizational value and performance as it brings new insights and perspectives and provides a basis for equity and fairness for various stakeholders (Broadbridge, Hearn, Huse, \& Grethe Solberg, 2006; Letendre, 2004). Women are argued to have necessary traits that are needed for good governance, since women are naturally more scrupulous, decent at decision-making, sophisticated in accounting and finance and risk adverse (Azmi \& Barrett, 2013). Contrasting results were found in studies, as the presence of female members has both positive and negative impact on firm profitability (Campbell \& Mínguez-Vera, 2008; Darmadi, 2011; Torchia, Calabrò, \& Huse, 2011).

The role of the non- executive director (NED) is often described as that of a long-term, consensus-based decision maker and as a custodian of the governance process (Higgs, 2003). Non-executive directors, essentially play an advisory role in the board meetings (Rashid \& Lodh, 2011; Uadiale, 2010). The presence of high number of non-executive directors ensures that managers are answerable to the shareholders - thus more likely to enhance performance, to have more power over the egotistical managers and to decrease financial fraud and protect 
the interests of shareholders (Romano \& Guerrini, 2012; Waweru, 2014). According to the Combined Code on Corporate Governance (2003), one of the responsibilities of NED is to satisfy themselves on the integrity of financial information and that financial controls and systems of risk management are robust and defensible. Contrasting studies found different relationships between non-executive directors and firm performance (Fich \& Shivdasani, 2006; Hossain, Prevost, \& Rao, 2001). However, one study in particular found a significant positive association between the presence of nonexecutive directors and firm value, especially in countries where legal protection for shareholders is weak (Dahya, Dimitrov, \& McConnell, 2008).

Similarly, the proportion of large institutional investors owning shares in the company, commonly referred to as institutional investors is also another important corporate governance tool. It is hypothesized that the higher the proportion of large institutional investors, the greater the monitoring role of these investors, and hence the greater the chance of better financial performance (Al-Matari, Al-Swidi, Fadzil, Fadzil, \& Al-Matari, 2012). Institutional investors play a vital role in global capital markets and create divergent effects on firm performance. They possess greater expertise in efficiently monitoring the board as well as altering the existing power distributions of a firm (Muniandy, Tanewski, \& Johl, 2016; Sacristán-Navarro, Gómez-Ansón, \& Cabeza-García, 2011). Research finds that institutional investors are more likely to invest in firms with governance practices that concur with their fiduciary duties and to reduce their costs of monitoring (Bushee \& Noe, 2000). The use of leverage also dictates corporate governance practices of a firm, as it restricts managerial discretion and wastage of free cash flow (Jensen, 1986).

Corporate governance in MNCs shares many common elements with corporate governance in domestic firms. Conventional mechanisms of corporate governance such as ownership concentration, board member participation, and executive compensation apply to both. Still, however, corporate governance differs between MNCs and domestic firms in several ways. First, MNCs have to deal with more demanding and more diverse global shareholders and stakeholder groups that seek greater disclosure and more transparent explanations for major decisions (Freeman \& Reed, 1983). For geographically diversified MNCs, especially those cross-listed in multiple nations, a high percentage of shareholders may be dispersed around the world with varying anticipations, preferences and needs. This situation results in greater coordination costs and governance complexity in boardrooms and executive offices. Second, as a growing number of MNCs become listed on multiple exchanges in multiple countries, and certain overseas units become independently listed on host country exchanges, MNC corporate governance has also become much more complex and subject to many more institutional constraints. For instance, MNCs that are active in Europe, North America and Japan may have to comply with both Anglo-American (stock-market capitalism) and relational-insider (welfare capitalism) governance systems simultaneously (Kim \& Limpaphayom, 1998; La Porta, Lopez-de-Silanes, Shleifer, \& Vishny, 2000). Third, unlike domestic firms that normally have only one board and one executive team, MNCs may have several boards or executive teams at different levels or in different countries. These multi-tier boards collectively comprise the total corporate governance structure for an MNC; yet these 


\section{MInstitute Macrothink $_{\text {Int }}$}

International Journal of Accounting and Financial Reporting

ISSN 2162-3082

hierarchical tiers are sequentially interrelated. This structure leads to a large array of globally scattered principals (especially foreign shareholders), and the corporate governance framework is subject to institutional and legal constraints dispersed over many different countries.

In terms of the corporate governance practices of Bangladesh, it can be observed that most of the companies are family owned or controlled by corporate groups or the government. Surveys found that the top five shareholders hold more than $50 \%$ of a firm's outstanding stocks on an average in Bangladeshi listed companies, while sponsor shareholders hold $73 \%$ of the board composition of non-bank listed companies in Bangladesh (Farooque, van Zijl, Dunstan, \& Karim, 2007; Sobhan \& Werner, 2003). Most of the listed companies in Bangladesh except multinationals are dominated by family members and head of the family becomes the chairman and other family members occupy important posts such as the CEO or the managing director (Brennan et al., 2008). As MNCs have not been explored in the corporate governance spectrum of Bangladesh properly, this study aims to explore how these factors are associated with MNC firm performance.

\section{Objective}

This research will aim to fulfill the following objectives:

- To provide an analysis of the corporate governance environment among the MNCs of Bangladesh.

- To measure the effect of the Corporate Governance on the financial performance of the Multinational Companies in Bangladesh.

- To contribute to the previously unexplored knowledge base in research on corporate governance and MNC firm performance of Bangladesh.

\section{Methodology}

This study focuses on evaluating the empirical relationship between firm's profitability and different corporate governance mechanisms. It is a cross-sectional research, analyzing the MNCs listed on the Dhaka Stock Exchange (DSE). Data for these MNCs were collected and analyzed from their audited annual reports for 8 years, from 2008 till 2015, considering 14 MNCs listed in the DSE. Panel Least Squares (PLS) method was used for estimating the unknown parameters in a linear regression model, with the goal of minimizing the differences between the observed responses in some arbitrary dataset and the responses predicted by the linear approximation of the data. Primary focus of this research is to test the following core hypothesis:

$\mathrm{H}_{0}$ : Corporate governance mechanisms have no significant relationship with $\mathrm{MNC}$ profitability.

$\mathrm{H}_{1}$ : Corporate governance mechanisms have significant relationship with MNC profitability 


\section{Mll Macrothink}

International Journal of Accounting and Financial Reporting

ISSN 2162-3082

2017, Vol. 7, No. 2

\subsection{Regression Model}

Using panel data collected from the annual reports, the following model was developed from previous literature, considering Return on Asset (ROA) as the dependent variable,

$$
\begin{gathered}
R O A=\beta_{0}+\beta_{1} B O A R D \_S I Z E+\beta_{2} C E O \_D U A L I T Y+\beta_{3} F E M A L E+\beta_{4} I N S T \\
+\beta_{5} L E V E R A G E+\beta_{6} N E D+\varepsilon_{t}
\end{gathered}
$$

Here,

Table 1. Identification of variables

\begin{tabular}{ll}
\hline \multicolumn{1}{c}{ Symbol } & \multicolumn{1}{c}{ Variable Name } \\
\hline ROA & Return on Asset (Dependent Variable) \\
\hline BOARD_SIZE & Board Size (Number of board members) \\
\hline CEO_DUALITY & CEO Duality (Dummy Variable, 1 if CEO duality exists, 0 if not) \\
\hline NED & Number of Non-Executive Directors \\
\hline LEV & Leverage \\
\hline INST & Institutional Investors \\
\hline FEMALE & Number of Female board members \\
\hline
\end{tabular}

\section{Findings and Analysis}

\subsection{Descriptive Statistics}

Table 2 represents the summary statistics of the variables of this study. Total observations of this study were 112 , owing to a time period of 8 years and 14 listed MNCs. Descriptive statistics suggest that the commercial banks of Bangladesh are highly levered, with an average Debt to Equity ratio standing at $97 \%$. It has a maximum value of $547 \%$ for one particular company of the sample, implying that some MNCs take on debt five times to its equity capital. Another important observation is from the statistics of female board members. Maximum number of female board member any MNC had was only two, with an average figure of 0.55. Many MNCs had no female members, thereby highlighting the lack of diversity among boards. 
Table 2. Descriptive statistics

\begin{tabular}{lccccc}
\hline \multicolumn{1}{c}{ Variables } & Mean & Median & Maximum & Minimum & $\begin{array}{c}\text { Standard } \\
\text { Deviation }\end{array}$ \\
\hline Return on Asset & 0.149120 & 0.143250 & 0.516400 & 0.117900 & 0.097807 \\
\hline $\begin{array}{l}\text { Board Size (Number of } \\
\text { board members) }\end{array}$ & 8.169643 & 8.000000 & 11.000000 & 5.000000 & 1.438771 \\
\hline CEO Duality & 0.598214 & 1.000000 & 1.000000 & 0.000000 & 0.492462 \\
\hline $\begin{array}{l}\text { Number of Non-Executive } \\
\text { Directors }\end{array}$ & 0.213113 & 0.166700 & 0.600000 & 0.090900 & 0.114030 \\
\hline Leverage & 0.965988 & 0.786600 & 5.471000 & 0.080900 & 0.736508 \\
\hline $\begin{array}{l}\text { Institutional Investors } \\
\text { Number of Female board }\end{array}$ & 0.304871 & 0.274150 & 0.860000 & 0.066600 & 0.165811 \\
\hline \begin{tabular}{l} 
members \\
\hline
\end{tabular} & & 0.500000 & 2.000000 & 0.000000 & 0.583379 \\
\hline
\end{tabular}

\subsection{Regression}

In the OLS regression model, ROA is regressed against all the dependent variables. Table 3 represents the outputs of the regression, with $10 \%$ level of significance.

Table 3. Regression estimates (The p values with * denotes significance in $10 \%$ level.)

\begin{tabular}{ccc}
\hline Independent Variables & $\begin{array}{c}\text { Coefficient } \\
\text { Values }\end{array}$ & Probability (Significance) \\
\hline Intercept & 0.195686 & $(0.0009)^{*}$ \\
\hline Board Size & 0.004453 & $(0.4753)$ \\
\hline CEO Duality & -0.069402 & $(0.0002)^{*}$ \\
\hline Female Board Members & 0.005675 & $(0.7164)$ \\
\hline Institutional & -0.006821 & $(0.8991)$ \\
Shareholders & & \\
\hline Leverage & -0.051250 & $(0.0000)^{*}$ \\
\hline $\begin{array}{c}\text { Number of } \\
\text { Non-Executive Directors }\end{array}$ & 0.034923 & $(0.6425)$ \\
\hline P-Value & 0.000038 & \\
\hline R ${ }^{2}$ & $24.54 \%$ & \\
\hline Adjusted R & $20.22 \%$ & \\
\hline
\end{tabular}




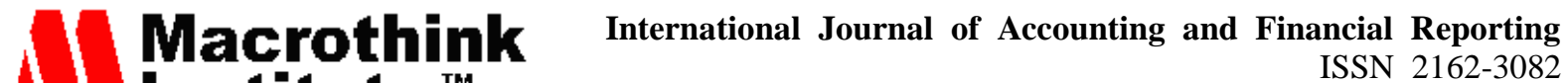 2017, Vol. 7, No. 2}

\subsection{Discussion of the Findings}

As evident by the regression output, only CEO duality and leverage were significant at $10 \%$ significance level. However, the coefficient figures bring up some interesting remarks. For example, CEO duality has a negative coefficient, signifying that the presence of duality in the board brings down MNC performance. It relates to the school of literature voicing the negative impact of CEO duality on firm performance (Brown \& Caylor, 2006; Duru, Iyengar, \& Zampelli, 2016; Rechner \& Dalton, 1991). Leverage also seem to have a negative impact on MNC performance, generating consensus that firms are overloading on debt and should instead be focusing on more equity as sources of capital. While taking debt does provide benefits to magnify profitability, the same cannot be said for the MNCs listed in Bangladesh.

Looking into several other core corporate governance tools considered in this research, board size seems to have a positive impact on firm performance. It would imply that the typical MNC boards have not yet reached the optimal point, and there are still rooms for growing in this aspect. While many researchers constantly vouch for larger boards (Mak \& Kusnadi, 2005; Zabri et al., 2016), there is still no optimal board size determined and opting for larger boards might be detrimental to firm performance (Aldehayyat et al., 2016; Morekwa Nyamongo \& Temesgen, 2013; Obradovich \& Gill, 2012).

However in contrast to existing literature on higher proportion of institutional ownership leads to better financial performance, this research showed a negative relationship for Bangladeshi listed MNCs. This particular findings of the study is quite baffling, as researchers commonly agree that institutional ownership usually leads to better governance practices and improved information disclosure (Boone \& White, 2015; Muniandy et al., 2016). Since this particular variable was not significant in this regression, it might be due to a small sample of only 14 listed MNCs for this study. Similarly, even though the number of non-executive directors also had a positive impact on firm performance, it was not statistically significant which might be attributed to smaller sample size. This particular finding is in line with the literature which stated how a bigger portion of non-executive directors would bring improved firm performance in countries where legal protection for the shareholders are weak (Burkart \& Panunzi, 2006; Cueto \& Switzer, 2015). Bangladesh, with its political instability and level of corruption existing in different areas of the economy, is surely one of those countries with fragile legal protection (Nurunnabi, Hossain, \& Al-Mosa, 2016). Thereby, a positive relation in such case is highly welcomed and should be pursued by the MNCs to restore investor's confidence.

\section{Conclusion}

Bangladesh has generally been acknowledged as a country where most publicly listed companies are family controlled. These companies are mostly controlled by families through direct and indirect (termed as "beneficial") ownership (Biswas, 2015). They are also involved in the management of these companies through personal or family ties. As such, when both the owners and the managers are from the same family, there might be both positive and negative repercussions for the shareholders. While these controlling families are more prone to caring for firm's long-term prospect and committing better human capital for the firm, 


\section{MlMacrothink}

International Journal of Accounting and Financial Reporting ISSN 2162-3082

minority shareholders might fall victim due to managerial entrenchment, abnormal compensations paid to family members and lack of takeover mechanisms at play (Enriques \& Volpin, 2007; Johansen \& Schoar, 2006). In such an economy with majority companies being family controlled, MNCs might seem as alternative investment opportunities with better governance practices due to their reputation and operating procedures. On this particular context, not much empirical work exists on governance practices by MNCs in developing markets. This study aimed to fulfill this gap by focusing on the listed MNCs of Bangladesh. As evident from the findings, most of it relates to existing literature on domestic firms. Being a developing market, it still lags behind on female composition on controlling party of companies and MNCs are also not further behind in this case. According to the regression results it is evident that CEO duality and leverage ratio have significant relationship to profitability of MNCs. Moreover, the positive relationships within profitability and various corporate governance factors i.e. board size, female board members and proportion of independent directors signify that Bangladeshi listed firms are yet to reach the optimal level which would significantly ensure ideal performance.

This study, like many others focusing on developing countries, suffers from lack of data. Only 14 listed MNCs were found in the Dhaka Stock Exchange, with 8 years of annual reports available. Therefore, while relationships were found to be similar to the literature, it could not be exploited further. Huge doubt also exists on the quality of these financial statements, as study showed alarming rate of falsification of information on both local and international businesses conducted in Bangladesh (Nurunnabi et al., 2016). Thus, future research could investigate similar models across a bigger dataset, possibly considering regional integrations to show detailed effects. Furthermore, future research could explore the reasons behind the possible discrepancies in several contemporary and trending governance mechanisms and their possible implications for local and international policymakers and business entities.

\section{Acknowledgement}

The research is funded by the Centre for Business Policy Research (CBPR), Independent University, Bangladesh (IUB).

\section{References}

Aguilera, R. V., \& Jackson, G. (2003). The cross-national diversity of corporate governance: Dimensions and determinants. Academy of management Review, 28(3), 447-465.

Al-Malkawi, H.-A. N., Pillai, R., \& Bhatti, M. (2014). Corporate governance practices in emerging markets: The case of GCC countries. Economic Modelling, 38, 133-141.

Al-Matari, Y. A., Al-Swidi, A. K., Fadzil, F. H. B., Fadzil, H., \& Al-Matari, E. M. (2012). Board of Directors, Audit Committee Characteristics and the Performance of Saudi Arabia Listed Companies. International Review of Management and Marketing, 2(4), 241. 


\section{Mll Macrothink}

International Journal of Accounting and Financial Reporting

ISSN 2162-3082

2017, Vol. 7, No. 2

Alam Choudhury, M., \& Nurul Alam, M. (2013). Corporate governance in Islamic perspective. International Journal of Islamic and Middle Eastern Finance and Management, 6(3), 180-199.

Aldehayyat, J. S., Alsoboa, S. S., \& Al-Kilani, M. H. (2016). Investigating How Corporate Governance Affects Performance of Firm in Small Emerging Markets: An Empirical Analysis for Jordanian Manufacturing Firms. International Business Research, 10(1), 77.

Ammann, M., Oesch, D., \& Schmid, M. M. (2011). Corporate governance and firm value: International evidence. Journal of Empirical Finance, 18(1), 36-55.

Azmi, I. A. G., \& Barrett, M. A. (2013). Women on boards and company financial performance: A study of Malaysian SMEs. Paper presented at the Proceedings of 3rd global accounting, finance and economics conference, Melbourne, Australia.

Bebchuk, L., Cohen, A., \& Ferrell, A. (2009). What matters in corporate governance? Review of Financial studies, 22(2), 783-827.

Bhagat, S., \& Bolton, B. (2013). Director ownership, governance, and performance. Journal of Financial and Quantitative Analysis, 48(01), 105-135.

Biswas, P. K. (2015). Corporate governance reforms in emerging countries: A case study of Bangladesh. International Journal of Disclosure and Governance, 12(1), 1-28.

Bonn, I., Yoshikawa, T., \& Phan, P. H. (2004). Effects of board structure on firm performance: A comparison between Japan and Australia. Asian Business \& Management, $3(1), 105-125$.

Boone, A. L., \& White, J. T. (2015). The effect of institutional ownership on firm transparency and information production. Journal of financial economics, 117(3), 508-533.

Boyd, B. K. (1995). CEO duality and firm performance: A contingency model. Strategic Management Journal, 16(4), 301-312.

Brennan, N. M., Solomon, J., Uddin, S., \& Choudhury, J. (2008). Rationality, traditionalism and the state of corporate governance mechanisms: Illustrations from a less-developed country. Accounting, Auditing \& Accountability Journal, 21(7), 1026-1051.

Brickley, J. A., Coles, J. L., \& Jarrell, G. (1997). Leadership structure: Separating the CEO and chairman of the board. Journal of corporate Finance, 3(3), 189-220.

Broadbridge, A., Hearn, J., Huse, M., \& Grethe Solberg, A. (2006). Gender-related boardroom dynamics: How Scandinavian women make and can make contributions on corporate boards. Women in Management Review, 21(2), 113-130.

Brown, L. D., \& Caylor, M. L. (2006). Corporate governance and firm valuation. Journal of accounting and public policy, 25(4), 409-434.

Burkart, M., \& Panunzi, F. (2006). Agency conflicts, ownership concentration, and legal shareholder protection. Journal of Financial Intermediation, 15(1), 1-31. 


\section{MInstitute Macrothink $_{\text {Int }}$}

International Journal of Accounting and Financial Reporting

ISSN 2162-3082

Bushee, B. J., \& Noe, C. F. (2000). Corporate disclosure practices, institutional investors, and stock return volatility. Journal of Accounting Research, 171-202.

Campbell, K., \& Mínguez-Vera, A. (2008). Gender diversity in the boardroom and firm financial performance. Journal of Business Ethics, 83(3), 435-451.

Cerbioni, F., \& Parbonetti, A. (2007). Exploring the effects of corporate governance on intellectual capital disclosure: an analysis of European biotechnology companies. European Accounting Review, 16(4), 791-826.

Coles, J. L., Daniel, N. D., \& Naveen, L. (2008). Boards: Does one size fit all? Journal of Financial Economics, 87(2), 329-356.

Cremers, M., \& Ferrell, A. (2009). Thirty years of corporate governance: Firm valuation \& stock returns. Revise and resubmit at Journal of Finance.

Cueto, D. C., \& Switzer, L. N. (2015). Intraday market liquidity, corporate governance, and ownership structure in markets with weak shareholder protection: evidence from Brazil and Chile. Journal of Management \& Governance, 19(2), 395-419.

Dahya, J., Dimitrov, O., \& McConnell, J. J. (2008). Dominant shareholders, corporate boards, and corporate value: A cross-country analysis. Journal of Financial Economics, 87(1), 73-100.

Darmadi, S. (2011). Board diversity and firm performance: the Indonesian evidence. Corporate ownership and control Journal, 8.

$\mathrm{Du}, \mathrm{H}$. (2006). Round Table Discussion on corporate governance guidelines of SEC and its implementation practices in Bangladesh. Dhaka: Asian Development Bank.

Duru, A., Iyengar, R. J., \& Zampelli, E. M. (2016). The dynamic relationship between CEO duality and firm performance: The moderating role of board independence. Journal of Business Research, 69(10), 4269-4277.

Ehikioya, B. I. (2009). Corporate governance structure and firm performance in developing economies: evidence from Nigeria. Corporate Governance: The international journal of business in society, 9(3), 231-243.

Enriques, L., \& Volpin, P. (2007). Corporate governance reforms in continental Europe. The Journal of Economic Perspectives, 21(1), 117-140.

Farooque, O. A., van Zijl, T., Dunstan, K., \& Karim, A. W. (2007). Ownership structure and corporate performance: Evidence from Bangladesh. Asia-Pacific Journal of Accounting \& Economics, 14(2), 127-149.

Fich, E. M., \& Shivdasani, A. (2006). Are busy boards effective monitors? the Journal of Finance, 61(2), 689-724. 


\section{Mll Macrothink}

International Journal of Accounting and Financial Reporting

ISSN 2162-3082 2017, Vol. 7, No. 2

Finkelstein, S., \& D'aveni, R. A. (1994). CEO duality as a double-edged sword: How boards of directors balance entrenchment avoidance and unity of command. Academy of Management Journal, 37(5), 1079-1108.

Florackis, C. (2008). Agency costs and corporate governance mechanisms: evidence for UK firms. International Journal of Managerial Finance, 4(1), 37-59.

Freeman, R. E., \& Reed, D. L. (1983). Stockholders and stakeholders: A new perspective on corporate governance. California management review, 25(3), 88-106.

Gillibrand, M. (2004). Corporate management essential for industrialization. The Bangladesh Observer.

Gompers, P. A., Ishii, J. L., \& Metrick, A. (2001). Corporate governance and equity prices.

Heidrick, S. (2007). 10th Annual Corporate Board Effectiveness Study. Los Angeles, California: Center for Effective Organizations, 1-40.

Higgs, D. (2003). Review of the role and effectiveness of non-executive directors. Stationery Office.

Hossain, M., Prevost, A. K., \& Rao, R. P. (2001). Corporate governance in New Zealand: The effect of the 1993 Companies Act on the relation between board composition and firm performance. Pacific-Basin Finance Journal, 9(2), 119-145.

Jensen, M. C. (1986). Agency costs of free cash flow, corporate finance, and takeovers. The American Economic Review, 76(2), 323-329.

Jensen, M. C. (1993). The modern industrial revolution, exit, and the failure of internal control systems. the Journal of Finance, 48(3), 831-880.

Johansen, B., \& Schoar, A. (2006). The role of family in family firms. The Journal of Economic Perspectives, 20(2), 73-96.

Johnson, S. A., Moorman, T. C., \& Sorescu, S. (2009). A reexamination of corporate governance and equity prices. Review of Financial Studies, hhp018.

Kasri, R. (2009). Corporate governance: conventional vs. Islamic perspective. Islamic Perspective.

Kim, K. A., \& Limpaphayom, P. (1998). A test of the two - tier corporate governance structure: The case of Japanese keiretsu. Journal of Financial Research, 21(1), 37-51.

La Porta, R., Lopez-de-Silanes, F., Shleifer, A., \& Vishny, R. (2000). Investor protection and corporate governance. Journal of financial economics, 58(1), 3-27.

Letendre, L. (2004). The dynamics of the boardroom. The Academy of Management Executive, 18(1), 101-104.

Madura, J. (2012). International financial management. Cengage Learning. 


\section{MInstitute ${ }^{\text {Macrothink }}$}

International Journal of Accounting and Financial Reporting

ISSN 2162-3082

2017, Vol. 7, No. 2

Mak, Y. T., \& Kusnadi, Y. (2005). Size really matters: Further evidence on the negative relationship between board size and firm value. Pacific-Basin Finance Journal, 13(3), 301-318.

Mcconomy, B., \& Bujaki, M. (2000). Management trends Corporate Governance. Enhancing shareholder value. CMA Management, 74(8), 10-13.

Morekwa Nyamongo, E., \& Temesgen, K. (2013). The effect of governance on performance of commercial banks in Kenya: a panel study. Corporate Governance: The international journal of business in society, 13(3), 236-248.

Muniandy, P., Tanewski, G., \& Johl, S. K. (2016). Institutional investors in Australia: do they play a homogenous monitoring role? Pacific-Basin Finance Journal, 40, 266-288.

Nurunnabi, M., Hossain, M. A., \& Al-Mosa, S. A. (2016). Ceci n'est pas une pipe! Corporate Governance practices under two political regimes in Bangladesh: A political economy perspective. International Journal of Disclosure and Governance, 13(4), 329-363.

Obradovich, J., \& Gill, A. (2012). The Impact of Corporate Governance and Financial Leverage on the Value of American Firms. International Research Journal of Finance and Economics, (91).

Obradovich, J., \& Gill, A. (2013). The impact of corporate governance and financial leverage on the value of American firms.

Panasian, C., Prevost, A. K., \& Bhabra, H. S. (2003). Board composition and firm performance: The case of the Dey report and publicly listed Canadian firms.

Rashid, M. A., \& Lodh, S. C. (2011). Corporate governance and performance of small and medium sized enterprise (SME): evidence from Bangladesh. Faculty of Commerce-Papers, $1-44$.

Rechner, P. L., \& Dalton, D. R. (1991). CEO duality and organizational performance: A longitudinal analysis. Strategic Management Journal, 12(2), 155-160.

Renders, A., Gaeremynck, A., \& Sercu, P. (2010). Corporate - Governance Ratings and Company Performance: A Cross - European Study. Corporate Governance: An International Review, 18(2), 87-106.

Romano, G., \& Guerrini, A. (2012). Corporate governance and accounting enforcement actions in Italy. Managerial Auditing Journal, 27(7), 622-638.

Sacristán-Navarro, M., Gómez-Ansón, S., \& Cabeza-García, L. (2011). Family ownership and control, the presence of other large shareholders, and firm performance: Further evidence. Family Business Review, 24(1), 71-93.

Shukeri, S. N., Shin, O. W., \& Shaari, M. S. (2012). Does board of director's characteristics affect firm performance? Evidence from Malaysian public listed companies. International Business Research, 5(9), 120. 


\section{MInstitute ${ }^{\text {Mink }}$}

International Journal of Accounting and Financial Reporting

ISSN 2162-3082

Smith, N., Smith, V., \& Verner, M. (2006). Do women in top management affect firm performance? A panel study of 2,500 Danish firms. International Journal of productivity and Performance Management, 55(7), 569-593.

Sobhan, E. F., \& Werner, W. (2003). A comparative analysis of corporate governance in South Asia: Charting a roadmap for Bangladesh.

Torchia, M., Calabrò, A., \& Huse, M. (2011). Women directors on corporate boards: From tokenism to critical mass. Journal of business ethics, 102(2), 299-317.

Tornyeva, K., \& Wereko, T. (2012). Corporate governance and firm performance: Evidence from the insurance sector of Ghana. European Journal of Business and Management.

Tricker, R. I. (1984). Corporate governance: Practices, procedures, and powers in British companies and their boards of directors. Gower Pub Co.

Uadiale, O. M. (2010). The impact of board structure on corporate financial performance in Nigeria. International Journal of Business and Management, 5(10), 155.

Waweru, N. (2014). Determinants of quality corporate governance in Sub-Saharan Africa: evidence from Kenya and South Africa. Managerial Auditing Journal, 29(5), 455-485.

Zabri, S. M., Ahmad, K., \& Wah, K. K. (2016). Corporate Governance Practices and Firm Performance: Evidence from Top 100 Public Listed Companies in Malaysia. Procedia Economics and Finance, 35, 287-296.

\section{Copyright Disclaimer}

Copyright for this article is retained by the author(s), with first publication rights granted to the journal.

This is an open-access article distributed under the terms and conditions of the Creative Commons Attribution license (http://creativecommons.org/licenses/by/4.0/) 